IRA-International Journal of Education \& Multidisciplinary Studies

ISSN 2455-2526; Vol.06, Issue 01 (2017)

Pg. no. 134-141

Institute of Research Advances

http://research-advances.org/index.php/IJEMS

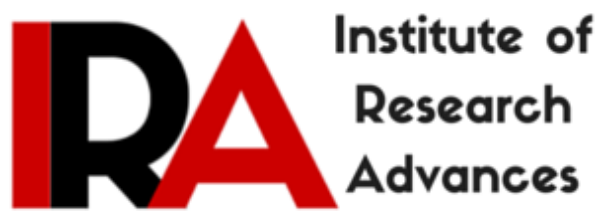

\title{
Effect on Administration Policies, the Public Service Quality and Satisfaction on the System Administration Manunggal under One Roof in Indonesia
}

\author{
Isa Ansari K ${ }^{1}$, Rahman Kadir ${ }^{2}$, Ansar A. ${ }^{3}$ \\ ${ }^{1,3}$ Indonesian Fighters University, Makassar South Sulawesi, Indonesia. \\ ${ }^{2}$ Hasanuddin University, Makassar South Sulawesi, Indonesia.
}

Type of Review: Peer Reviewed.

DOI: http://dx.doi.org/10.21013/jems.v6.n1.p10

\section{How to cite this paper:}

Ansari K, I., Kadir, R., \& Ansar, A. (2017). Effect on Administration Policies, the Public Service Quality and Satisfaction on the System Administration Manunggal under One Roof in Indonesia. IRA International Journal of Education and Multidisciplinary Studies (ISSN 24552526), 6(1), 134-141. doi:http://dx.doi.org/10.21013/jems.v6.n1.p10

(C) Institute of Research Advances

\section{(cc) $\mathrm{BY}-\mathrm{NC}$}

This work is licensed under a Creative Commons Attribution-Non Commercial 4.0 International License subject to proper citation to the publication source of the work.

Disclaimer: The scholarly papers as reviewed and published by the Institute of Research Advances (IRA) are the views and opinions of their respective authors and are not the views or opinions of the IRA. The IRA disclaims of any harm or loss caused due to the published content to any party. 


\begin{abstract}
This paper aims to test and analyze the influence of the Administration in the form of policy formulation, implementation and evaluation of the quality of service and the satisfaction of the public. This research was conducted on The Office of System Administration Manunggal under One Roof in Indonesia with a population of 5.292 people and carried out with formulations Slovin on the precision of 5\% with a total sample of 372 respondents. The study's hypotheses were tested using a model of Structural Equation Model (AMOS ver. 18). The study found that 1) directly in policy formulation and evaluation of policies and significant positive effect on the quality of service, while the implementation of policies have a positive impact and no significant effect on the quality of service; 2) direct policy formulation and evaluation of policies and significant positive effect on public satisfaction, and implementation of policies and no significant negative effect on public satisfaction; 3) the quality of the service directly positive and significant impact on public satisfaction; and 4) indirectly policy formulation and evaluation of policies through quality service and significant positive effect on public satisfaction, while policy implementation indirectly through service quality and no significant negative impact on public satisfaction.
\end{abstract}

Keywords: Conflict, Behavior, Legislative, Executive, Budgeting

\title{
Introduction
}

Services problems often expressed by the public, is always concerned with the assessment of the administrative policies run by the service provider to the recipient of the service. Criticism of the nature of the formulation, implementation and evaluation of administrative policies always lead to perceptions that were unfavorable to the public on the quality of service received and the public always show a sense of dissatisfaction with the service received, so in general the administration's policy there is a gap with the embodiment of the quality of service desired and the gap between the expected fulfillment.

The fact that observed in the activities of service one-stop system applied in Indonesia, such as in a service activity the documents, motor vehicles do in the Office of System Administration Manunggal under One Roof in Indonesia (SAMSAT), shows that the percentage of votes administration policy, quality services and public satisfaction is still perceived as unfavorable to the public, where the real service to the public should be aligned. Here is shown the data on the percentage level three service issues from multiple System Administration Manunggal under One Roof in Indonesia within the last 5 years:

Table 1 Indonesian System Administration Manunggal under One Roof (2012-2016)

\begin{tabular}{|c|c|c|c|}
\hline Year & $\begin{array}{c}\text { Policy Administration } \\
(\%)\end{array}$ & $\begin{array}{c}\text { Quality of Service } \\
(\%)\end{array}$ & $\begin{array}{c}\text { Public Satisfaction } \\
(\%)\end{array}$ \\
\hline 2011 & 61.6 & 65.7 & 62.7 \\
2012 & 63.2 & 70.8 & 60.3 \\
2013 & 62.9 & 71.3 & 64.9 \\
2014 & 62.8 & 68.5 & 62.7 \\
2015 & 59.7 & 67.9 & 61.9 \\
\hline Average & 62.0 & 68.8 & 62.5 \\
\hline
\end{tabular}

Source: Indonesian System Administration Manunggal under One Roof (Data processed, 2016)

Based on data from five years of the above, it is known that the level of assessment administration policies because of the way the government in this case the Office of Indonesian System Administration Manunggal under One Roof in doing the formulation, implementation and evaluation of service policies have been handled an average of $62 \%$, but service quality is still below expectations at an average of $68.8 \%$, so the level of public satisfaction with the service received an average of $62.5 \%$. 
These data indicate that administration policy issues in Indonesian System Administration Manunggal under One Roof Office have not formulated properly, especially with regard to the regulations implementing it, the preparation procedures and eligibility assessment services activities. Side implementation of the policy has not been actualized well, especially with regard to the implementation of the tactical, technical and practical for all service activities. As well as on the evaluation of the policy has not been actualized according assessment, the realization of achievement, the consequences of complaints and supervision provided.

Policy formulation is an activity that is easy to implement, transformed and have a clear principle of the rule of law in its implementation. The results of the follow-up formulations provide a clear implementation based systems, procedures and mechanisms. Formulations along with the implementation make it easy to evaluate a policy based on the achievement assessment and supervision work is done consistently (Nugroho, 2005).

As a result of prospective administrative policies that do not provide reinforcement to the administrator as service providers, raises issues of quality services that are less accepted by the public. The realization of the quality of service that do not fit the expectations seen from the dimensions of the services provided, mainly the lack of support for physical evidence of adequate services, the level of empathy service is lacking, reliability of service are less professional, friendly service response is less promising and guarantees low service for all completion. This is what makes the public perceived service quality is still lacking.

There are five dimensions of service quality required by the public which require services in accordance with the dimensions of the physical evidence, empathy, reliability, response and guarantees known as the concept of TERRA. This is a consideration for any service provider to pay attention to the dimensions of the service provided to the public, so that prospective and received appropriate service orientation of public expectations (Zeithaml, 2000).

Including as a result of an administrative policy that is less actualized properly, causing the public to feel unfulfilled satisfaction with the services provided by Indonesian System Administration Manunggal under One Roof Office. The realization of such dissatisfaction public usually show distaste, not happy, always protested and criticized the services provided. The fact a form of satisfaction felt so far by the public is not satisfied due to a price comparison service that is too expensive, the value of the service is low, service detriment, the service is not feasible, the design services that are not attractive, the accuracy of the airport is often not timely, services not reliable and long-chain distribution services. This has always been a problem that the public perceived the reception service was lacking and unsatisfactory from the Indonesian System Administration Manunggal under One Roof Office.

According Dulka (1994) is a good service that gives satisfaction. Interpretation of the public perceived satisfaction should include service attributes that satisfy its price, value, benefits, feasibility, design, accuracy, and service procedures. The better the administrative policy later supported by the quality of the services provided, the satisfaction of being an easy thing to realize. Based on the background described, the problems in this research are: 1) whether the formulation of administrative policy affects the quality of services and public satisfaction? 2) Whether the administrative policies such as the implementation affect the quality of services and public satisfaction? 3) Whether the evaluation of administrative policy affects the quality of services and public satisfaction? 4) Whether the effect on the service quality of public satisfaction? 5) Whether the form of administrative policy formulation, implementation and evaluation of public satisfaction through an effect on public satisfaction with one-stop service system in Indonesia? 


\section{Literature review and Hypotheses testing}

This study shows the direct relationship between the independent variables on the variable and the dependent variable. In this research, there are five variables observed is composed of three independent variables, an intermediate variable and one dependent variable. The independent variable of administration policy in this research consists of the formulation, implementation and evaluation, intermediate variable is the quality of service and the dependent variable is public satisfaction.

\section{Policy Formulation}

Basic free variable selection policy formulation based on the formulation of the theory put forward Drucker (1999) that the formulation of public policy is formulated based limitations on what actions have to be done or not done by the government. Rasphati (2011) showed that the formulation have a negative and no significant effect on the service quality and public satisfaction. Study findings demonstrated inconsistencies in Yasin becek (2014); Rohimon (2015) that the policy formulation positive and significant impact on the service quality and public satisfaction.

$\mathrm{H}_{1 \mathrm{a}} \quad$ formulation has a positive and significant effect on services quality

$\mathrm{H}_{1 b}$ formulation has a positive and significant effect on public satisfaction.

\section{Policy Implementation}

Basic election independent variable policy implementation based on the theory proposed implementation Stoner (1996) that the implementation of the policy is intervention in identifying the problem, asserted the goals to be achieved and designing the structure of a systematic implementation process. Policy implementation is the policy of implementation of an activity or action to be processed reach the goal.

Implementation of the quality of services and public satisfaction researched Sinan Bhatia (2005) showed that the implementation of administration policies has a positive but not significant effect on the service quality and public satisfaction. Inconsistency findings proved Zeeshan (2008) that the implementation of administration policies has a negative and significant effect on the services quality and public satisfaction. Another fact is evidenced in studies Ustman Khan (2015) that the implementation has a positive but no significant effect on the service quality and public satisfaction.

$\mathrm{H}_{2 \mathrm{a}} \quad$ Implementation has a positive and significant effect on service quality.

$\mathrm{H}_{2 \mathrm{~b}} \quad$ Implementation has a positive and significant effect on public satisfaction

\section{Policy Evaluation}

Selection variable policy evaluation based on the theory proposed evaluation Dunn (1999) that evaluation is an assessment of how effectively public policies in order to fully accounted for in accordance goals achieved and assess the gap between expectation and reality. Each policy must be evaluated before it was replaced, so there should be a clause that can be replaced after being evaluated. Sinan Faiz (2009); Naship (2011) showed that the evaluation has a negative and not significant effect on the service quality and public satisfaction. Other findings were a little different, that the evaluation had a positive effect and no significant on the services quality and public satisfaction (Robert, 2010).

$\mathrm{H}_{3 \mathrm{a}} \quad$ Evaluation has a positive and significant effect on service quality.

$\mathrm{H}_{3 \mathrm{~b}} \quad$ Evaluate has a positive and significant effect on public satisfaction

\section{Quality of Service}

Selection of the variable quality of service based on the service quality theory put forward Wyckof (1996) that the quality of service as the expected level of excellence and control over the level of excellence to meet the wishes of the public. The quality of service is not seen from the viewpoint of the organizers or the service provider, but based on the public's perception of the service recipient. And feel it is the public who use the services provided, so that it is the public who should assess and determine quality of service. Saif (2009) that the quality of service is a significant negative effect on public satisfaction. Different 
evidence indicated M. Tala (2011) shows the quality of service policy is positive and not significant to public satisfaction. Similar facts evidenced Ambar (2010) that the service quality had a positive influence and not significant to public satisfaction.

$\mathrm{H}_{4} \quad$ Service quality has a positive and significant effect on public satisfaction.

Public satisfaction

Similarly, the theoretical basis that builds the dependent variable is public satisfaction. This refers to the theories expressed public satisfaction index (Dulka, 1994) that public satisfaction can be measured by the satisfaction attributes form consisting of relationships between a set price, the value of the service, the advantages of service, eligibility services, design services, the accuracy and reliability of services, and the types of services in a business. Research on quality of service for the public satisfaction, among others, Mohammad (2015) showed service quality had a positive and not significant on public satisfaction. Inconsistency indicated at studies Hayan Samaan (2015) showed service quality has a positive and not significant to public satisfaction.

$\mathrm{H}_{5 \mathrm{a}}$ formulation of administration policies through service quality has a positive and significant effect on public satisfaction.

$\mathrm{H}_{5 \mathrm{~b}} \quad$ Implementation of administration policies through service quality has a positive and significant effect on public satisfaction.

$\mathrm{H}_{5 \mathrm{c}} \quad$ Evaluation of administration policies through service quality has a positive and significant effect on public satisfaction.

\section{Methodology}

This study is an exploratory that seeks to find relationships that are relatively new and explanatory research that is done by way of explaining the symptoms caused by an object of research. 5.292 people at the total population. Furthermore, the selected sample size determination using the formula Slovin. So the sample in this study was 372 people. Data analysis techniques used in explaining the phenomenon in this study is a descriptive statistical analysis techniques and analysis of Structural Equation Modeling (SEM).

\section{Discussion and Analysis}

Based on the method of determining the value in the model, the first model testing variables are grouped into exogenous variables and endogenous variables. Exogenous variables are a variable whose value is determined outside the model. While endogenous variable is a variable whose value is determined by an equation or model-established relationships. Included in the group of exogenous variables is the measurement of policy formulation, policy implementation and evaluation of policies, while those classified as an endogenous variable is the quality of services and public satisfaction. The model is said to be good if the development of hypothetical model theoretically supported by empirical data. From the evaluation of the eight criteria model shows a goodness of fit indices seen the value of chi-square still great and the overall criteria are not in accordance with values, cutoff the specified so that the modification of the model by performing the correlation between error indicator according to the instructions of the modification indices. The test results are evaluated based on the model of goodness of fit indices in Table 2 following the criteria presented models as well as critical values that have compatibility data. 
IRA-International Journal of Education \& Multidisciplinary Studies

Table 2 Goodness of Fit Indices Overall Model

\begin{tabular}{|c|c|c|c|c|c|}
\hline $\begin{array}{c}\text { Goodness of } \\
\text { fit index }\end{array}$ & $\begin{array}{c}\text { Cut-off } \\
\text { Value }\end{array}$ & $\begin{array}{c}\text { Early stage } \\
\text { Model }\end{array}$ & Annotation & $\begin{array}{c}\text { Final stage } \\
\text { Model }\end{array}$ & Annotation \\
\hline Chi_Square & Small & 593.405 & Marginal & 170.325 & favourable \\
\hline Probability & $\geq 0.05$ & 0.000 & Marginal & 0.500 & favourable \\
\hline CMIN/DF & $\leq 2.00$ & 2.982 & Marginal & 0.996 & favourable \\
\hline RMSEA & $\leq 0.08$ & 0.092 & Marginal & 0.000 & favourable \\
\hline GFI & $\geq 0.90$ & 0.815 & Marginal & 0.939 & favourable \\
\hline AGFI & $\geq 0.90$ & 0.765 & Marginal & 0.910 & favourable \\
\hline TLI & $\geq 0.94$ & 0.682 & Marginal & 1.001 & favourable \\
\hline CFI & $\geq 0.94$ & 0.726 & Marginal & 1.000 & favourable \\
\hline
\end{tabular}

Source:: Structural Equation Model (AMOS, Data processed, 2016)

The evaluation results indicate the model for the early stages of the eight criteria of goodness of fit indices none meet the criteria for a cut-off will value, which be modified according to the instructions of the model modification indices, as previously described. After the modification of the model, then the final stage shows throughout the criterion of goodness of fit indices have met the criteria or according to criteria of the cut-off value, so that the model can be said to have been in accordance with the criteria of goodness of fit indices for analysis.

The explaining of direct and indirect effect to explained of causality between exogenous variables and intervening variables on endogenous variables. The test results are presented in the following table:

Table 3 Direct and Indirect Effect

\begin{tabular}{|c|c|c|c|c|c|}
\hline \multirow{2}{*}{ Hypo. } & Exogenous & Endogenous & \multicolumn{2}{|c|}{ path coefficient value (Direct Effect) } \\
\cline { 4 - 6 } & & Standardize & P-Value & Annotation \\
\hline 1 & $\begin{array}{c}\text { policy } \\
\text { formulation }\left(\mathrm{X}_{1}\right)\end{array}$ & $\begin{array}{c}\text { Quality of service } \\
(\mathrm{Y})\end{array}$ & 0,243 & 0,000 & supported \\
\hline 2 & $\begin{array}{c}\text { policy } \\
\text { implementation } \\
\left(\mathrm{X}_{2}\right)\end{array}$ & $\begin{array}{c}\text { Quality of service } \\
(\mathrm{Y})\end{array}$ & 0,092 & 0,098 & $\begin{array}{c}\text { partially } \\
\text { supported }\end{array}$ \\
\hline 3 & $\begin{array}{c}\text { policy evaluation } \\
\left(\mathrm{X}_{3}\right)\end{array}$ & $\begin{array}{c}\text { Quality of service } \\
(\mathrm{Y})\end{array}$ & 0,219 & 0,026 & supported \\
\hline 4 & $\begin{array}{c}\text { policy } \\
\text { formulation }\left(\mathrm{X}_{1}\right)\end{array}$ & $\begin{array}{c}\text { public satisfaction } \\
(\mathrm{Z})\end{array}$ & 0,258 & 0,000 & supported \\
\hline
\end{tabular}


IRA-International Journal of Education \& Multidisciplinary Studies

\begin{tabular}{|c|c|c|c|c|c|}
\hline 5 & $\begin{array}{c}\text { policy } \\
\text { implementation } \\
\left(\mathrm{X}_{2}\right)\end{array}$ & $\begin{array}{c}\text { public satisfaction } \\
(\mathrm{Z})\end{array}$ & $-0,093$ & 0,098 & rejected \\
\hline 6 & $\begin{array}{c}\text { policy evaluation } \\
\left(\mathrm{X}_{3}\right)\end{array}$ & $\begin{array}{c}\text { public satisfaction } \\
(\mathrm{Z})\end{array}$ & 0,215 & 0,034 & supported \\
\hline 7 & $\begin{array}{c}\text { Quality of service } \\
(\mathrm{Y})\end{array}$ & $\begin{array}{c}\text { public satisfaction } \\
(\mathrm{Z})\end{array}$ & 0,881 & 0,000 & supported \\
\hline \multicolumn{7}{|c|}{ path coefficient value (Indirect Effect) } \\
\hline 8 & $\begin{array}{c}\text { Exogenous } \\
\text { policy }\end{array}$ & $\begin{array}{c}\text { intervening } \\
\text { Quality of } \\
\text { service (Y) }\end{array}$ & $\begin{array}{c}\text { Endogenous } \\
\text { satisfaction } \\
(\mathrm{Z})\end{array}$ & Standardize & Annotation \\
\hline 9 & $\begin{array}{c}\text { policy } \\
\text { implementation } \\
\left(\mathrm{X}_{2}\right)\end{array}$ & $\begin{array}{c}\text { Quality of } \\
\text { service (Y) }\end{array}$ & $\begin{array}{c}\text { public } \\
\text { satisfaction } \\
(\mathrm{Z})\end{array}$ & $-0,088$ & supported \\
\hline 10 & $\begin{array}{c}\text { policy evaluation } \\
\left(\mathrm{X}_{3}\right)\end{array}$ & $\begin{array}{c}\text { Quality of } \\
\text { service }(\mathrm{Y})\end{array}$ & $\begin{array}{c}\text { public } \\
\text { satisfaction } \\
(\mathrm{Z})\end{array}$ & 0,210 & supported \\
\hline
\end{tabular}

Source: Structural Equation Model (AMOS, Data processed, 2016)

From the whole of the model there are five lines directly affect positive and significant, one-lane direct positive influence and insignificant, as well as the one-lane direct influence negative and insignificant. Furthermore, there are two paths indirect effect a significant and positive and one negative path and not significant. The interpretation of Table 3 can be explained as follows:

a. The formulation of a policy directly positive effect for 0,243 and 0,000 significantly on service quality.

b. Implementation of a policy directly positive but not significant effect for 0,092 and 0,098 on service quality.

c. Evaluation of policies directly affects a positive and significant effect for 0,219 and 0,026 on service quality.

d. Policy formulation directly had a positive and significant effect for 0,258 and 0,000 on public satisfaction.

e. Implementation of policies directly affected negatively by $-0,093$ and 0,098 are not significant on the public satisfaction.

f. Evaluation of policies directly affects a significant positive for 0,215 and 0,034 on the public satisfaction.

g. The service quality is directly positive effect for 0,881 and 0,000 significantly on public satisfaction.

h. Formulation of policies indirectly through the positive of service quality for 0,223 and 0,000 significantly on public satisfaction.

i. Implementation of policies indirectly through negative influence service quality for $-0,088$ and 0,098 are not significant on the public satisfaction.

j. Evaluate policies indirectly through the positive influence of service quality 0,210 for and 0.034 significant on public satisfaction.

\section{Conclusion}

Based on the research that has been described, it is concluded: 1) direct policy formulation and evaluation of policies and significant positive effect on the quality of service, while the implementation of policies have a positive impact and no significant effect on the quality of service; 2) direct policy formulation and 
evaluation of policies and significant positive effect on public satisfaction, and implementation of policies and no significant negative effect on public satisfaction; 3 ) the quality of the service directly positive and significant impact on public satisfaction; and 4) indirectly policy formulation and evaluation of policies through quality service and significant positive effect on public satisfaction, while policy implementation indirectly through service quality and no significant negative impact on public satisfaction.

\section{References}

1. Agus Dwiyanto. 2003. Reform of Governance and Autonomy. Yogyakarta: Center for the Study of population Uniiversitas Gajah Mada.

2. Ambar, W. 2010. Bureaucracy in Modern Society. Jakarta: UI Press.

3. David Osborne and Peter Plastrik. 2000. Trimming Bureaucracy, Lima strategy, Towards Entrepreneurial Government. Jakarta: Victory Jaya Abadi.

4. David Osborne and Ted Gaebler. 2004. Reinventing Government, Laboratories of Democracy,in Yeremias T. Keban, Six-D images Strategic Public Administration, Concepts, Theory and Issue. Yogjakarta: Style media.

5. Dunn, William, 1996. The New Public Service: Serving Not Steering, ME Sharpe Inc. 2003: New York.

6. Parasuraman A .1990. Delevering Balancing Customer Service Quality perception and Expectations. New York: The Free Press.

7. Rohimon Widodo. 2015. "Participatory Planning and Governance Paradigm Shift" in Alexander Abe, the Participatory Planning. Yogyakarta: Publisher Pembaruan.

8. Saif Khan. 1999. Public Service Performance Bureucratic Corruption in Indonesia. Yogyakarta: Gadjah Mada University.

9. Sinan Faiz, 2009. Principles of Formulation wisdom of the State. Jakarta: Bina Script.

10. Warsito Utomo. 2006. New Public Administration Indonesia, Paradigm Shift of Public Administration to Public Administration. Yogyakarta: Student Library.

11. Wyckof, Steven. 1996. Total Quality Management in Government: "A Practical Guide for the Real World". San Francisco: Jossey Bass Inc.

12. Yeremias. Keban, 2004. Six D images Strategic Public Administration, Concepts, Theory and Issue. 33. Yogjakarta thing: Style media. 